\title{
KERAGAMAN GENETIK DAN KEKERABATAN GENOTIP KACANG BAMBARA (Vigna subteranea L.) LOKAL JAWA BARAT
}

\section{GENETIC DIVERSITY AND RELATIONSHIP OF BAMBARA GROUNDNUT (Vigna subteranea L.) GENOTYPE LANDRACES OF WEST JAVA}

\author{
Enceng Sobari ${ }^{1)}$ dan Noladhi Wicaksana ${ }^{2)}$ \\ ${ }^{1}$ Program Studi Agroindustri Politeknik Negeri Subang Jl. Arif Rahman Hakim No.8 (Islamic \\ Center) Cigadung, Subang 41212 \\ ${ }^{2}$ Fakultas Pertanian Universitas Padjadjaran Jl. Raya Bandung-Sumedang Km. 21 Jatinangor \\ Sumedang 45363
}

Korespondensi : ncesobari@gmail.com ${ }^{1)}$,noladhi@yahoo.com ${ }^{2)}$

Diterima 4 Oktober 2017/Disetujui 21 Desember 2017

\begin{abstract}
ABSTRAK
Kacang bambara (Vigna subterranea) merupakan salah satu tanaman yang kurang mendapatkan perhatian sebagai bahan pangan di Indonesia atau underutilized. Kacang bambara memiliki potensi untuk dikembangkan dan dapat dimanfaatkan sebagai sumber pangan alternatif di Indonesia. Kacang bambara sangat bervariasi dan memiliki tingkat adaptasi wilayah yang sangat luas. Penelitian dilaksanakan di kebun percobaan Ciparanje, Universitas Padjadjaran. Penelitian dimulai bulan September 2014 sampai dengan bulan Maret 2015 menggunakan Rancangan Acak Kelompok (RAK) diulang dua kali. Menggunakan 30 genotip kacang bambara lokal hasil eksplorasi di beberapa wilayah Jawa Barat (Bandung, Tasikmalaya, Garut, Sumedang, Bogor, Majalengka) dan wilayah Jawa Timur sebagai kontrol (Lamongan dan Madura). Hasil penelitian menunjukkan variabilitas genetik kacang bambara lokal di beberapa wilayah Jawa Barat menunjukkan kriteria luas pada karakter bobot polong segar, bobot polong kering, bobot 100 biji, bobot per plot. Genotip-genotip yang memiliki banyak kemiripan karakter berdasarkan jarak koefisien Euclidian, memiliki hubungan kekerabatan yang dekat.
\end{abstract}

Kata kunci : Genotip lokal, Kacang Bambara, Kekerabatan, Keragaman genetik, Vigna subteranea L.

\begin{abstract}
Bambara groundnut (Vigna subteranea L.) is one of underutliized crops in Indonesia. Bambara groundnut is potential to be developed and can be utilized as an alternative food source in Indonesia. Bambara groundnut greatly varies and has a very wide area of adaptation. The experiment was conducted at the experimental field station at Ciparanje in Padjadjaran University. Starting on September 2014 until March 2015 with Randomized Block Design (RBD) and repeated two times. The research used 30 accessions originally from various locations in West Java (Bandung, Tasikmalaya, Garut, Sumedang, Bogor, Majalengka) and East Java (Lamongan, Madura). Genetic variability of Bambara groundnut landrace in some West Java
\end{abstract}


showed broad criteria on the characters fresh pod weight, dry pod weight, weight of 100 seeds, and weight per plot. Genotypes which had many similarities in some characters based on euclidian distance coefficient had close relationship.

Keywords: Bambara groundnut, Genetic Variability, Landrace Genetic, Relationship, Vigna subteranea $\mathrm{L}$.

\section{PENDAHULUAN}

Sebagai salah satu bentuk upaya memecahkan persoalan menghadapi kerawanan pangan di Indonesia, pemerintah mengeluarkan kebijakan yang berkaitan dengan diversifikasi pangan yang dinyatakan dalam Peraturan Presiden (Perpres) No 22 tahun 2009 tentang Kebijakan Percepatan Penganekaragaman Konsumsi Pangan Berbasis Sumber Daya Lokal dan Peraturan Menteri Pertanian Nomor 43/Permentan/OT.140/10/2009 tentang Gerakan Percepatan Penganekaragaman Konsumsi Pangan Berbasis Sumber Daya Lokal.

Kacang bambara (Vigna subteranea L.) merupakan tanaman lokal yang memiliki potensi yang baik untuk dikembangkan. Kendala saat ini masyarakat belum banyak mengenal potensi yang dimiliki tanaman bambara tersebut. Perhatian dan minat sebagian para peneliti juga masih kurang terhadap tanaman bambara ini. Genotip lokal mempunyai peranan penting untuk program pemuliaan tanaman salah satunya melalui pemanfaatan variabilitas genetik yang dilanjutkan dengan seleksi dan evaluasi daya hasil (Austi et al., 2014). Kacang bambara memiliki kandungan nutrisi yang banyak, dan dapat dijadikan sebagai sumber protein penting. Kandungan gizi didalamnya terdapat 53,1\% karbohidrat, $6,1 \%$ lemak, $17,4 \%$ protein, $6,1 \%$ serat, $3,4 \%$ abu, 0,098\% kalsium, 0,007\% besi, 1,2\% kalium dan 0,003\% natrium (Onwubiko et al., 2011), sedangkan pada setiap biji kering terdapat $16-21 \%$ protein, $50-60 \%$ karbohidrat dan 4,5-6,5\% lemak (Wicaksana et al., 2013).

Penelitian ini dilakukan untuk memperoleh keragaman karakter yang dapat berkontribusi pada hasil produksi dan jarak hubungan kekerabatan antar genotip.

\section{BAHAN DAN METODE}

Penelitian dimulai bulan September 2014 sampai dengan bulan Maret 2015 menggunakan Rancangan Acak Kelompok (RAK) diulang dua kali. Menggunakan 30 genotip kacang bambara lokal hasil eksplorasi di beberapa wilayah Jawa Barat dan Jawa Timur sebagai kontrol yaitu Bandung, Tasikmalaya, Garut, Sumedang, Bogor, Majalengka, Lamongan dan Madura (Tabel 1).

Benih ditanam pada masing-masing plot dengan jarak tanam $60 \times 40 \mathrm{~cm}$. Tiap plot percobaan terdiri dari 50 tanaman. diberi perlakuan fungisida dengan bahan aktif metalaxyl 35\%. Pupuk sesuai dengan standar kebutuhan yang direkomendasikan terdiri dari Urea $200 \mathrm{~kg} \mathrm{ha}^{-1}, \mathrm{SP}-36150 \mathrm{~kg}$ $\mathrm{ha}^{-1}$, dan KCl $100 \mathrm{~kg} \mathrm{ha}^{-1}$.

Variabel yang diamati meliputi panjang biji, lebar biji, tebal biji, panjang polong, lebar polong, jumlah biji per tanaman, bobot biji kering per tanaman, bobot polong segar per tanaman, bobot polong kering per tanaman, bobot 100 biji, bobot per plot. 
Tabel 1. Daftar Genotip Kacang Bambara

\begin{tabular}{|c|c|c|c|}
\hline No & Genotip & Daerah & Asal \\
\hline 1 & KB-28(6)2 & Rajapolah & Tasikmalaya \\
\hline 2 & KB-25(3)2 & Rajapolah & Tasikmalaya \\
\hline 3 & KB-23(3)2 & Rajapolah & Tasikmalaya \\
\hline 4 & KB-21(2) & Rajapolah & Tasikmalaya \\
\hline 5 & KB-12(2) & Cikurubuk & Tasikmalaya \\
\hline 6 & KB-7(3) & Kota Garut & Garut \\
\hline 7 & KB-7(2) & Kota Garut & Garut \\
\hline 8 & KB-4(3) & Kota Garut & Garut \\
\hline 9 & KB-4(4) & Kota Garut & Garut \\
\hline 10 & KB-4(2) & Kota Garut & Garut \\
\hline 11 & KB-29(4) & Situraja & Sumedang \\
\hline 12 & KB-29(2) & Situraja & Sumedang \\
\hline 13 & KB-29(10)2 & Situraja & Sumedang \\
\hline 14 & KB-29(7)1 & Situraja & Sumedang \\
\hline 15 & KB-29(3)1 & Situraja & Sumedang \\
\hline 16 & KB-29(1)1 & Situraja & Sumedang \\
\hline 17 & KB-31(3) & Situraja & Sumedang \\
\hline 18 & KB-32(3) & Situraja & Sumedang \\
\hline 19 & KB-54(1) & Cicalengka & Bandung \\
\hline 20 & KB-55(2)2 & Cicalengka & Bandung \\
\hline 21 & KB-51(1)1 & Cicalengka & Bandung \\
\hline 22 & KB-52(3)2 & Cicalengka & Bandung \\
\hline 23 & KB-40(1)1 & Bangkalan & Madura \\
\hline 24 & KB-41(3) & Bangkalan & Madura \\
\hline 25 & KB-46(5) & Kota Bogor & Bogor \\
\hline 26 & KB-46(2) & Kota Bogor & Bogor \\
\hline 27 & $\mathrm{~KB}-2(1)$ & Lamongan & Lamongan \\
\hline 28 & KB-2(4) & Lamongan & Lamongan \\
\hline 29 & KB-2(5) & Lamongan & Lamongan \\
\hline 30 & KB-8(9) & Majalengka & Majalengka \\
\hline
\end{tabular}

Parameter genetik dihitung berdasarkan metode yang dipakai Singh dan Chaudhary (1979). Varians dihitung berdasarkan persamaan yang digunakan dalam pendugaan varians genetik, varians lingkungan dan varians fenotip (Boer, 2011) yaitu :

$$
\begin{aligned}
& \sigma_{g}^{2}=\sigma_{g}^{2}=\frac{M 2-M 1}{n} \\
& \sigma_{e}^{2}=\frac{\sigma_{e}^{2}}{n}=\frac{M 1}{n}
\end{aligned}
$$

$\sigma_{f}^{2}=\sigma_{g}^{2}+\sigma_{e}^{2}=\sigma_{g}^{2}+\sigma_{\frac{e}{n}}^{2}$

Keterangan :

$\sigma_{g}^{2}=$ Varians genotip

$\sigma_{e}^{2}=$ Varian lingkungan

$\sigma_{f}^{2}=$ Varian Fenotip

Karakter memiliki variabilitas luas apabila nilai varians genetik $\sigma_{g}^{2}$ lebih besar dari pada dua kali standar deviasi varians genetik $\sigma_{g}^{2}$ dan variabilitas genetik dikatakan sempit apabila nilai varians genetik $\sigma_{g}^{2}$ lebih kecil dari pada dua kali standar deviasi varians genetik.

Rumus standar deviasi varians genotipik dan varians fenotipik adalah sebagai berikut (Pinaria et al. 1995):

$\sigma_{\sigma_{g}^{2}}=\sqrt{\frac{2}{r^{2}}\left[\frac{\text { Kt genotipe }}{d b \text { genotipe }+2}\right]+\left[\frac{\text { Kt }_{\text {galat }}{ }^{2}}{d b \text { galat }+2}\right]}$

$\sigma_{\sigma_{f}^{2}}=\sqrt{\frac{2}{r^{2}}\left[\frac{\text { Kt genotipe }}{\text { db genotipe }+2}\right]}$

Koefesien varians genetik (KVG) dan Koefesien varians fenotip (KVF) berdasarkan rumus parameter genetik yang digunakan adalah sebagai berikut :

$$
\begin{aligned}
& \mathrm{KVG}=\frac{\sqrt{\sigma_{g}^{2}}}{x} \times 100 \% \\
& \mathrm{KVF}=\frac{\sqrt{\sigma_{f}^{2}}}{x} \times 100 \%
\end{aligned}
$$

Dimana ;

$\sigma_{g}^{2}=$ Varians genetik

$\sigma_{f}^{2}=$ Varians fenotip

$x=$ Rata-rata Umum

Heritabilitas didefinisikan sebagai rasio varians genetik untuk varians fenotipik 
(Fehr, 1996). Menggunakan rumus heritabilitas arti luas yaitu :

Untuk melihat kekerabatan genetik dan menduga jarak genetik berdasarkan kemiripan antar objek yang diteliti dianalisis melalui program NTSYS pc 2.02 (Wicaksana et al., 2013).

\section{HASIL DAN PEMBAHASAN}

\section{Keragaman Genetik Kacang Bambara}

Hasil penelitian menujukkan keragaman antara genotip dengan menghitung varians genetik, varian fenotip, KVG dan heritabilitas dapat dilihat pada (Tabel 2).

Hasil analisis yang menunjukkan tingginya nilai varians fenotip disertai

$$
h^{2}=\frac{\sigma_{g}^{2}}{\sigma_{f}^{2}}
$$

dengan nilai varians genetik yang rendah pada karakter yang diamati selama percobaan terhadap kacang bambara. Pada karakter bobot polong segar, bobot polong kering, bobot 100 biji dan bobot per plot memiliki variasi yang luas, mampu memberikan kesempatan yang luas pula untuk memilih karakter tanaman unggul berdasarkan karakter tersebut. Analisis keragaman genetik berguna untuk mengetahui pola pengelompokan genotip yang diidentifikasi dan untuk mengetahui karakter dari setiap kelompok genotip yang terbentuk, sehingga dapat digunakan dalam kegiatan seleksi untuk perakitan varietas unggul baru (Dualembang et al., 2011).

Tabel 2. Nilai Varians Fenotip, Varians Genotip, KVG dan Heritabilitas Kacang Bambara

\begin{tabular}{|c|c|c|c|c|c|c|c|c|}
\hline Karakter & $\sigma_{f}^{2}$ & Stdev & $\begin{array}{c}\text { Kriteria } \\
\sigma_{f}^{2} \\
\end{array}$ & $\sigma_{g}^{2}$ & Stdev & $\begin{array}{c}\text { Kriteria } \\
\sigma_{g}^{2} \\
\end{array}$ & $h^{2}$ & $\begin{array}{l}\text { KVG } \\
(\%)\end{array}$ \\
\hline Panjang Biji & 0,019 & 0,276 & Sempit & 0,007 & 0,167 & Sempit & 0,36 & 5,80 \\
\hline Lebar Biji & 0,012 & 0,219 & Sempit & 0,001 & 0,063 & Sempit & 0,07 & 2,80 \\
\hline Tebal Biji & 0,014 & 0,237 & Sempit & 0,002 & 0,089 & Sempit & 0,14 & 4,30 \\
\hline $\begin{array}{l}\text { Panjang } \\
\text { Polong }\end{array}$ & 0,044 & 0,420 & Sempit & 0,003 & 0,110 & Sempit & 0,06 & 2,50 \\
\hline Lebar Polong & 0,015 & 0,245 & Sempit & 0,004 & 0,126 & Sempit & 0,24 & 4,00 \\
\hline Jumlah Biji & 50,184 & 14,168 & Luas & 1,564 & 2,501 & Sempit & 0,03 & 9,70 \\
\hline $\begin{array}{l}\text { Bobot Biji } \\
\text { Kering }\end{array}$ & 39,635 & 12,591 & Luas & 1,960 & 2,800 & Sempit & 0,05 & 11,60 \\
\hline $\begin{array}{l}\text { Bobot Polong } \\
\text { Segar }\end{array}$ & 2269,583 & 95,280 & Luas & 18,176 & 8,527 & Luas & 0,01 & 6,40 \\
\hline $\begin{array}{l}\text { Bobot Polong } \\
\text { Kering }\end{array}$ & 283,262 & 33,661 & Luas & 4,267 & 4,131 & Luas & 0,02 & 7,20 \\
\hline Bobot 100 Biji & 362,557 & 38,082 & Luas & 27,627 & 10,512 & Luas & 0,08 & 6,10 \\
\hline $\begin{array}{l}\text { Bobot Per } \\
\text { Plot }\end{array}$ & 53974,964 & 464,650 & Luas & 2252,267 & 94,916 & Luas & 0,04 & 8,40 \\
\hline
\end{tabular}

Keterangan :

- Luas jika $\sigma_{g}^{2}>$ dari Stdev dan sempit jika $\sigma_{g}^{2}<$ dari Stdev genotip; Luas jika $\sigma_{f}^{2}>$ dari Stdev dan sempit jika $\sigma_{f}^{2}<$ dari Stdev fenotip.

- Kriteria Tinggi jika $h^{2}>0,5$ sedang jika $0,2 \leq h 2 \leq 0,5 h^{2}$ rendah jika $h^{2}<0,2$ (Stansfield, 1983).

- $\quad$ KVG = Koefisien Variasi Genotip; Stdev = Standar deviasi 
Karakter panjang biji, lebar biji, tebal biji, panjang polong, lebar polong, bobot biji kering, jumlah biji menunjukkan keragaman yang sempit. Hal ini diartikan bahwa seleksi terhadap tujuh karakter- karakter tersebut tidak akan efektif meskipun variabilitas fenotipnya tinggi, sebab pada dasarnya perbedaan fenotip yang ada disebabkan oleh pengaruh lingkungan. Keragaman genetik dengan kriteria sempit menunjukkan bahwa seleksi terhadap karakter pada beberapa varietas dan galur tersebut sudah tidak efektif (Sugandi, 2012). Menurut Sutjahjo et al. (2007) keragaman genetik sempit menandakan rendahnya variabilitas genetik pada karakter tersebut. Nilai mutlak KVG karakter kacang bambara berkisar 2,50 \% sampai 11,60 \%. Setiap karakter mempunyai kriteria variasi yang berbeda, maka kriteria variasi diabsolutkan terhadap nilai variasi tertinggi (Jamilah et al., 2011).

Nilai heritabilitas pada semua karakter memiliki nilai yang berbeda-beda. Kisaran nilai heritabilitas terrendah pada karakter bobot polong segar 0,01 dan tertinggi pada karakter panjang biji 0,36 (Tabel 2). Nilai heritabilitas yang tinggi tersebut menunjukkan bahwa pengaruh faktor genetik lebih besar terhadap penampilan fenotipik. Sutjahjo et al. (2007) faktor yang dapat mempengaruhi nilai heritabilitas antara lain, sampel yang dievaluasi, metode estimasinya, karakteristik populasi, adanya pautan gen (linkage), pelaksanaan percobaan, dan generasi populasi yang diuji Fehr (1987) dan Hermiati (2004).

\section{Kekerabatan Genotip Kacang Bambara}

Berdasarkan pengelompokan menggunakan program NTSYS pc 2.02 dalam melakukan standarisasi, penyususnan matriks, koefisien euclidian serta analisis klaster.

Hasil pengelompokan berdasarkan analisis menunjukkan bahwa hubungan kekerabatan yang tinggi diantara genotipgenotip kacang bambara yang membentuk klaster dan subklaster. Hair et al. (2010) menyatakan bahwa perlunya mengukur jarak pusat cluster (centroid) dengan obyek untuk mengatasi data yang variabelnya berkorelasi.

Pengklasteran dibedakan berdasarkan kemiripan jarak genetik yang dimiliki setiap genotip yang ditandai dengan alur garis yang sama (Gambar 1). Terdapat dua klaster A dan B, pada klaster A terbagi menjadi dua subklaster yaitu $A 1$ dan $A 2$ yang terdiri dari genotip 12(2), 2(1), 7(3), 2(4), 4(2), 4(4), $52(3) 2,40(1) 1,46(2), 25(3) 2,23(3) 2,29(7) 1$, 8(9), 2(5), 29(10)2, 29(2), 29(4), 21(2), 41(3), 28(6)2, 46(5), 54(1), 55(2)2, 29(1)1, 32(3), 29(3)1, 7(2) dan 31(3), pada klaster A2 hanya pada genotip 4(3). Pada klaster B tidak terdapat subklaster, hanya genotip 51(1)1.

Hal tersebut disebabkan banyaknya karakter yang sama sehingga ketidakmiripannya menjadi dekat. Dapat diartikan bahwa kacang bambara lokal yang berada di beberapa wilayah memiliki banyak kemiripan karakter sehingga memiliki hubungan kekerabatan yang dekat. Terdapat genotip yang jarak koefisien euclidian dekat yaitu genotip 4(2) dan 2(4) (Gambar 1). Genotip-genotip dengan koefisien euclidian yang sangat dekat dapat dipertimbangan sebagai genotip yang memiliki kemiripan yang sangat tinggi.

Hal ini senada berdasarkan hasil penelitian yang pernah dilakukan Austi et. al., (2014) pada jenis lokal kacang bogor, hasilnya yang didapatkan dengan nilai 


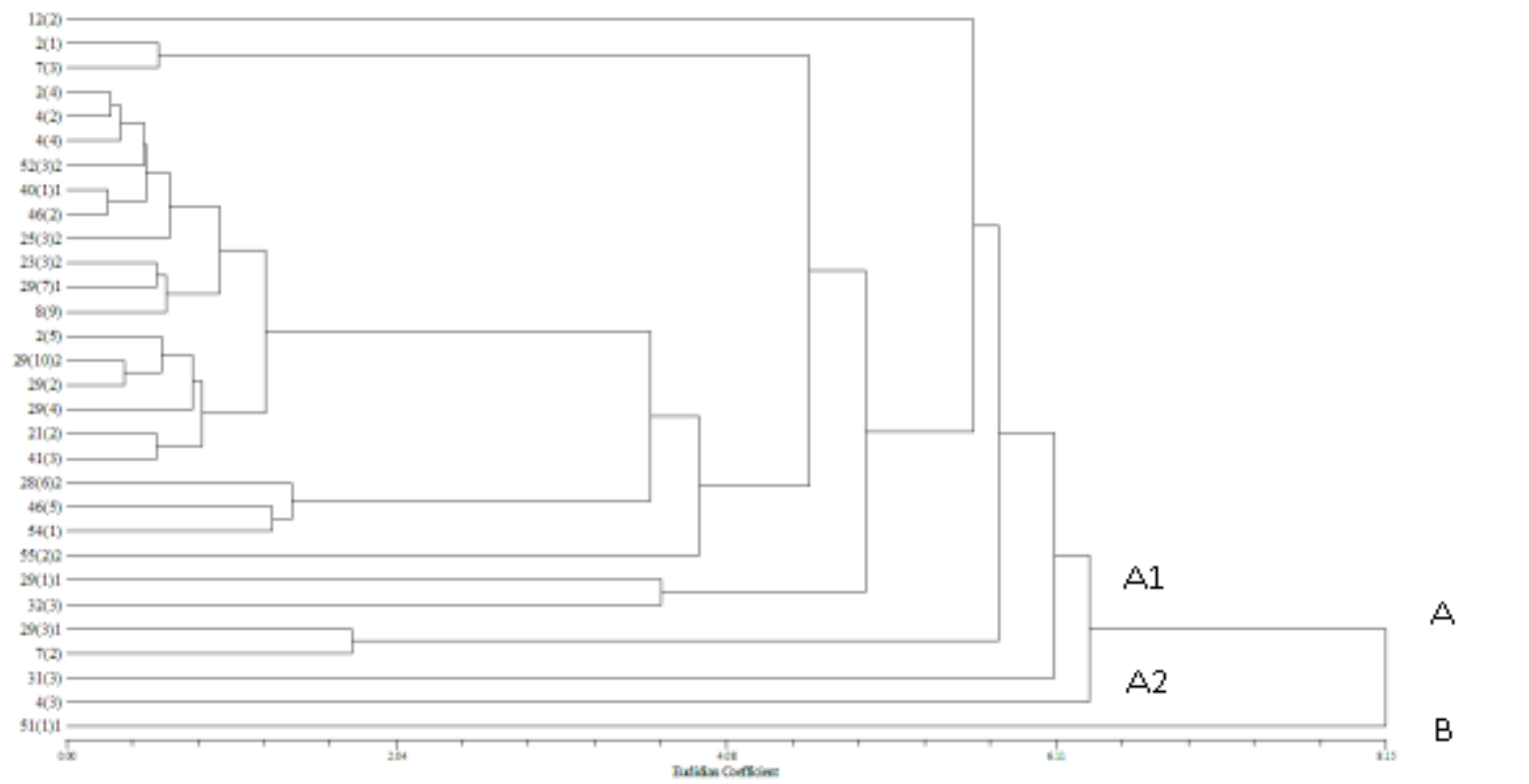

Gambar 1. Dendogram Variabilitas Genetik Kacang Bambara

kemiripan genetik yang tinggi dikatakan bahwa galur-galur lokal kacang bogor yang didapatkan memiliki keragaman yang sempit. Kesamaan sifat ini dikarenakan memiliki kekerabatan yang dekat atau karena perubahan sifat-sifat fenotip yang dipengaruhi oleh keadaan lingkungan.

\section{SIMPULAN}

1. Variabilitas genetik menunjukkan kriteria luas pada karakter bobot polong segar, bobot polong kering, bobot 100 biji, bobot per plot.

2. Kacang bambara lokal yang berada di beberapa wilayah Jawa Barat memiliki hubungan kekerabatan yang dekat.

\section{DAFTAR PUSTAKA}

Austi I. R., Damanhuri, dan Kuswanto. 2014. Keragaman dan kekerabatan pada proses penggaluran kacang bogor (Vigna subterranea L. Verdcourt) Jenis lokal. J. Produksi Tanaman, Vol. 2., No. 1: 73-79.

Boer. D., 2011. Genetic Variability and Path Coefficient Analysis for Some Agronomic and Physiology Characters of Seed Yield on Genetic Diversity of 54 Accessions of
Maize from East Indonesia. Jurnal Agroteknos Vol.1., No.1 : 35-43.

Dualembang, E., Musa, Y., Azrai, M., 2011. Karakterisasi Genetik Koleksi Plasma Nutfah Sorgum (Sorghum bicolor L. Moench) Berbasis Marka SSR (Simple Sequence Repeats).

Fehr, W. R., 1987. Principle of Cultivar Development. Vol. 1. New York. The Ronal press Co.

Hermiati, N., 2004. Diktat Dasar Pemuliaan Tanaman. Universitas Padjadjaran. Jatinangor. Hal 71.

Jamilah, C, Waluyo, B. dan Karuniawan, A., 2011. Parameter Genetik Aksesi Tanaman Kerabat Liar Ubi Jalar Koleksi Unpad Untuk Peningkatan dan Sumber Perbaikan Karakter Ubi Jalar. Makalah Seminar Nasional Pemuliaan Berbasis Potensi dan Kearifan Lokal Menghadapi Tantangan Globalisasi. Purwokerto, Jawa Tengah.

Onwubiko, N. C., Uguru, M. I., Ngwuta, A. A., Inyang, E. T. and Nnajiemere, O. J., 2011. Floral Biology of Bambara Groundnut [Vigna subterranea (L.) Verdc]. Journal of Plant Breeding and Crop Science Vol. 3(11). pp. 293-295. 
Pinaria, A., A. Baihaki, R. Setiamihardja, dan A.A. Darajat., 1995. Variabilitas Genetik dan heritabilitas Karakter-Karakter Biomasa 53 Genotip Kedelai. Zuriat, Vol. 6, No. 2 : 8-9.

Singh. R.K., and Chaudhary. B.D., 1979. Biometrical Methods in Quantitative Genetic Analysis. Kalyani Publishers. Ludhiana. New Delhi. 52-54 p.

Sugandi, R., Nurhidayah, T., Nurbaiti. 2012. Variabilitas Genetik dan Heritabilitas Karakter Agronomis Beberapa Varietas dan Galur Sorgum (Sorghum bicolor (L.) Moench). Universitas Riau. Riau.

Wicaksana. N., Hindun, Waluyo, B., Rachmadi, M., Karuniawan, A., dan Kurniawan, H., 2013. Karakterisasi Morfo-Agronomis Kacang Bambara (Vigna Subterranea L. verdc.) Asal Jawa Barat. Seminar Nasional 3 in 1 Peran Nyata Produk Hortikultura dan Agronomi Serta Program Pemuliaan Tanaman Terhadap Kontinyuitas Ketahanan Pangan Fakultas Pertanian Universitas Brawijaya-Peripi-Perhorti-Peragi.

Malang.
Sutjahjo, S.H., Rustikawati, A.W. dan Sandhi S.G., 2007. Kajian Genetik dan Seleksi Genotipe S5 Kacang Hijau (Vigna radiata) Menuju Kultivar Berdaya Hasil Tinggi dan Serempak Panen. Jurnal Penelitian dan Informasi Pertanian "Agrin", Vol. 11 No. 1, April 2007. ISSN: 1410-0029. 